УДК 629.45: 621.331: 681.518.54

ФОТОЕЛЕКТРИЧНА СИСТЕМА ПАСАЖИРСЬКОГО ВАГОНА

Канд. техн. наук В.В. Бондаренко, асист. Д.І. Скуріхін, магістрант М.В. Гончаренко

ФОТОЭЛЕКТРИЧЕСКАЯ СИСТЕМА ПАССАЖИРСКОГО ВАГОНА

Канд. техн. наук В.В. Бондаренко, ассист. Д.И. Скурихин, магистрант М.В. Гончаренко

\title{
PASSENGER CAR PHOTOVOLTAIC SYSTEM
}

Cand. of techn. sciences V.V. Bondarenko, assist. D.I. Skurihin, master student M.V. Goncharenko

Досліджена можливість застосування сонячної енергетики у сфері вагонного господарства. Досліджений рівень інсолячії за мармрутом прямування поїздів ХарківСімферополь та розрахована фотоелектрична система пасажирського вагона.

Ключові слова: сонячна енергетика, пасажирський вагон, фотоелектрична система, ФЕС, інсоляція.

Исследована возможность применения солнечной энергетики в сфрере вагонного хозяйства. Исследован уровень инсолячии по маршруту следования поездов ХарьковСимферополь и рассчитана фотоэлектрическая система пассажирского вагона.

Ключевые слова: солнечная энергетика, пассажирский вагон, фотоэлектрическая система, ФЭС, инсолящия.

The solar energy application in the field of passenger car management is proved in the article and designed $P V$ system of passenger car.

Keywords: solar energy, passenger cars, photovoltaic system, FES, insolation

Вступ. В Україні розвиток інфраструктури для отримання та споживання сонячної енергії вважається перспективним напрямком, оскільки середньорічний рівень інсоляції для більшості іiі територій є більшим, ніж у країнах Європи, які знаходяться на аналогічних широтах, а для півдня України відповідає рівню інсоляції країн південної Європи, у тому числі й Італії. У зв'язку з викладеним вище застосування сонячної енергії як альтернативного джерела електричної енергії для підприємств залізничної галузі та рухомого складу залізниць вважаємо актуальною проблемою, вирішення якої вимагає проведення щільних та всебічних досліджень.

Постановка проблеми у загальному вигляді та іï зв'язок із важливими науковими та практичними завданнями. Останнім часом в Україні та у світі велике значення приділяється застосуванню енергозберігаючих технологій i альтернативних джерел електричної та теплової енергії у різних галузях народного господарства. В значній мірі це стосується галузі вагонного господарства - як одного 3 великих споживачів енергії серед інших галузей держави. Для регіону України серед різних видів альтернативної енергетики значний інтерес з економічної, 
екологічної та енергетичної точок зору являє сонячна енергетика, оскільки: капітальні вкладення робляться тільки один раз, затрати при експлуатації мінімальні, 3 кожним роком вартість однієї кіловатгодини знижується завдяки підвищенню їх коефіцієнта корисної дії, джерело енергії невичерпне; експлуатація фотоелектричних елементів виключає забруднення навколишнього середовища; використання фотоелектричних елементів дозволяє отримувати енергію у будь-якому місці, куди неможливо підвести лінію електропередачі.

Враховуючи актуальність та перспективність використання сонячної енергетики в Україні, у роботі була поставлена задача дослідити можливість застосування сонячної енергетики у сфері вагонного господарства, дослідити рівень інсоляції за маршрутом прямування поїздів Харків-Сімферополь та розрахувати фотоелектричну систему пасажирського вагона.

Аналіз останніх досліджень i публікацій. Останніми роками вітчизняними та закордонними фахівцями активно досліджується перспектива використання альтернативних джерел енергії, насамперед сонячної, для отримання електричної та теплової енергії. Так, у ряді країн світу - США, Німеччині, Японії та ін. анонсовані державні програми, які націлені на заохочення населення та підприємств до використання сонячних елементів та сонячних колекторів. Наприклад, у Німеччині з 1997 року працюе програма "сто тисяч сонячних дахів", за якою держава купує залишки енергії у громадян, що встановили фотоелектричні панелі, за ціною у три рази дорожче за ринкові ціни. США також представили державну програму "мільйон сонячних дахів", за якою до 2010 року 1000000 будівель повинні бути обладнані сонячними батареями $[1,2,3]$.

Активно застосовуються сонячні батареї на транспорті (водному, повітряному та наземному). Існує також світова практика обладнання залізничного рухомого складу фотоелектричними елементами. Так, італійські інженери у 2005 році презентували перший поїзд, який працює за допомогою сонячної енергії (проект PVTRAIN) [4]. Сонячні панелі розміщені на даху вагона та поставляють енергію для систем кондиціювання, освітлення та безпеки поїзда.

Визначення мети та задачі дослідження. Аналіз вітчизняного i закордонного досвіду використання альтернативних джерел енергії та обгрунтування доцільності застосування сонячної енергетики у сфері вагонного господарства. Дослідження рівня сонячної радіації (інсоляції) за маршрутом прямування поїздів Харків-Сімферополь, будування та розрахунок фотоелектричної системи пасажирського вагона.

Основна частина дослідження. Загальна площа території України становить 603,7 тис. км², при цьому, рівень надходження сонячної радіації досить високий, він становить 3,46 мільярдів мегават-годин на рік. Найбільше число годин сонячного опромінення (23002400 годин на рік) спостерігається у Криму та на узбережжі Чорного i Азовського морів. У степовій зоні України тривалість сонячного опромінення становить 20002200 годин. У напрямку полісся та на сході країни тривалість сонячного опромінення зменшується до 1740-1840 годин, у низинах закарпатської області число годин сонячного опромінення досягає 2025 годин на рік. Найбільш сонячні місяці - із травня по серпень, найменш сонячні - 3 листопада по лютий. За кліматичними умовами Україну можна віднести до регіонів із сонячною радіацією середньої інтенсивності.

Кількість сонячної енергії, що припадає на одиницю площі, становить 1000-1350 кВт*год/м², при цьому, згідно 3 дослідженнями останніх років, в умовах України виробництво теплової енергії становить лише 500-600 кВт*\%од/м². 
Для оцінки геліоенергетичного

аналіз (табл. 1, 2).

потенціалу України наведемо порівняльний

Таблиця 1

\begin{tabular}{|c|c|c|c|c|c|}
\hline \multirow{2}{*}{ Період } & \multicolumn{2}{|c|}{$\begin{array}{c}\text { Сумарна сонячна радіація, що } \\
\text { досягає поверхні грунту по Україні }\end{array}$} & \multicolumn{2}{|c|}{ Еквівалентна кількість палива, млн т } \\
\cline { 2 - 6 } & МДж & кВт•год & $\begin{array}{c}\text { Газ } \\
\text { природний }\end{array}$ & $\begin{array}{c}\text { Кам’яне } \\
\text { вугілля }\end{array}$ & Нафта \\
\hline Січень & $4,53 \mathrm{E}+10$ & $1,26 \mathrm{E}+10$ & 1006 & 1677 & 1006 \\
\hline Липень & $3,62 \mathrm{E}+11$ & $1,01 \mathrm{E}+11$ & 8049 & 13416 & 8049 \\
\hline Рік & $2,44 \mathrm{E}+12$ & $6,79 \mathrm{E}+11$ & 54333 & 90555 & 54333 \\
\hline
\end{tabular}

Таблиця 2

\begin{tabular}{|c|c|c|}
\hline \multirow{2}{*}{ Період } & \multicolumn{2}{|c|}{ Сонячна радіація, що досягає поверхні грунту по Україні } \\
\hline & МДж/ $\mathrm{M}^{2}$ & кВт•год/м² \\
\hline Січень & 75 & 21 \\
\hline Липень & 600 & 167 \\
\hline Рік & 4050 & 1125 \\
\hline
\end{tabular}

3 табл. 1 та 2 можна зробити висновок, що на територію України за рік надходить така кількість енергії сонця, яка перевищує рівень іiі внутрішнього споживання більш ніж у п'ятсот разів. Тобто досить використовувати лише $0,5 \%$ енергії сонця, яка досягає поверхні України, щоб задовольнити енергетичні потреби українців.

Існують два основних способи використання сонячної енергії:

- безпосереднє перетворення в електричну енергію за допомогою сонячних фотоелектричних модулів.

- перетворення сонячної енергії в низькопотенціальну теплову енергію.

Перший спосіб $\epsilon$ найбільш привабливим з екологічної точки зору.

Основна проблема розвитку фотоенергетики - висока вартість електроенергії, однак найближчими роками прогнозується зростання виробництва сонячних батарей завдяки збільшенню їх ККД та удосконаленню технологій їх виготовлення. Що стосується другого способу - сонячного теплопостачання, то в Україні вже реалізовано більш 50 експериментальних проектів у різних галузях народного господарства. Річний виробіток теплової енергії досягає 500-

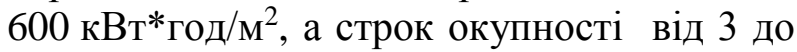
10 років.

3 метою дослідження рівня сонячної радіації (інсоляції) за маршрутом прямування поїздів сполученням ХарківСімферополь були зібрані та оброблені статистичні дані метеорологічних центрів [6], згідно 3 якими отримані географічні координати маршруту та відповідно до них було визначено рівні інсоляції через кожні 10 км протягом всього маршруту, який складає в цілому 683 км.

3 рис. 1 видно, що протягом маршруту поїзда має місце досить високий рівень сонячної радіації (від 3046 до $3703 \mathrm{Bт} / \mathrm{M}^{2} /$ день). При цьому середній рівень інсоляції на маршруті складає $3251 \mathrm{BT} / \mathrm{M}^{2} /$ день. Так, для порівняння, 


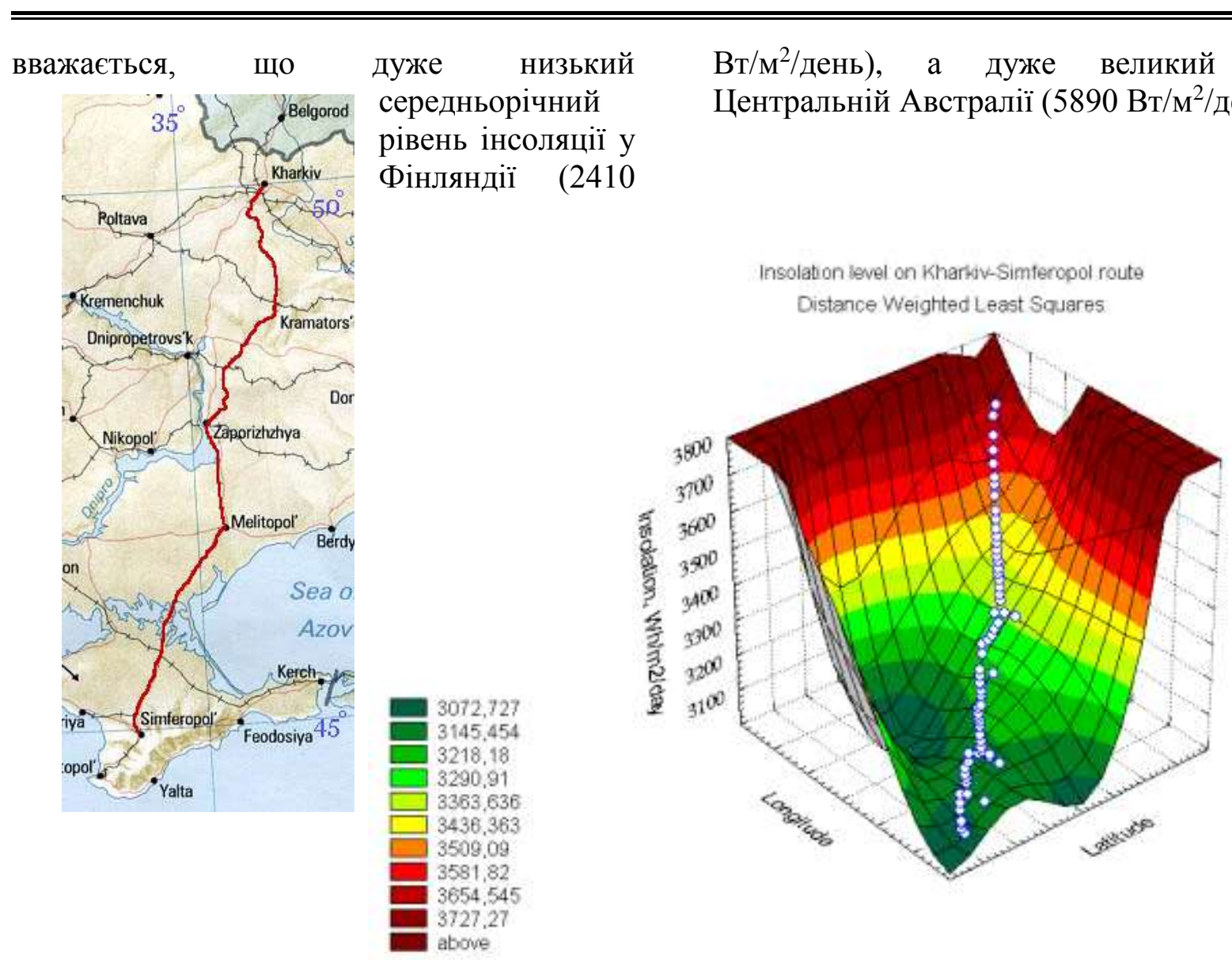

Рис. 1. Географічне розташування маршруту поїздів сполученням Харків-Сімферополь та зображення на тривимірному графіку залежності рівня сонячної радіації від географічних координат маршруту (“Latitude" - широта, "Longitude" - довгота, "Insolation" - інсоляція або сонячна радіація)

Нами була сформована фотоелектрична система вагона, яка зображена на рис. 2 [7]. За попередніми розрахунками, обладнавши сонячними батареями площину в $55 \mathrm{~m}^{2}$ даху вагона (загальна площина якого складає 78,85 м²), можна отримати близько 5 кВт електричної енергії, що складатиме за рік 93560 кВТ*год 3 одного вагона при середньому рівні інсоляції на маршруті у $3251 \mathrm{BT} / \mathrm{M}^{2} /$ день. На практиці фотоелектричні елементи можуть використовуватись як поодинці, так i збиратись у сонячні батареї (фотомодулі) для отримання потрібної потужності. Типова батарея номіналом $50 \mathrm{BT}$ складається із 36 послідовно з'єднаних сонячних елементів 100×100 мм². Така батарея в робочій точці розвиває $17 \mathrm{~B}$ при струмі 3 А при освітленні $100 \mathrm{MBT} / \mathrm{cm}^{2}$ [5]. Модуль виконаний у вигляді панелі, в алюмінієвому каркасі. Панель являє собою фотоелектричний генератор, який складається зі скляної плити, 3 тильних боків якої між двома шарами ламінуючої плівки розміщені сонячні елементи, які електрично поєднані між собою шинами. До внутрішнього боку модуля приєднаний блок терміналів, у якому розташовані електричні контакти, призначені для підключення модуля.

Найкращі сонячні елементи на даний момент мають коефіцієнт корисної дії більше $30 \%$, та строк служби близько 30- 
50 років, робота їх безшумна, окрім цього, фотоелектричні елементи мають велику

надійність.

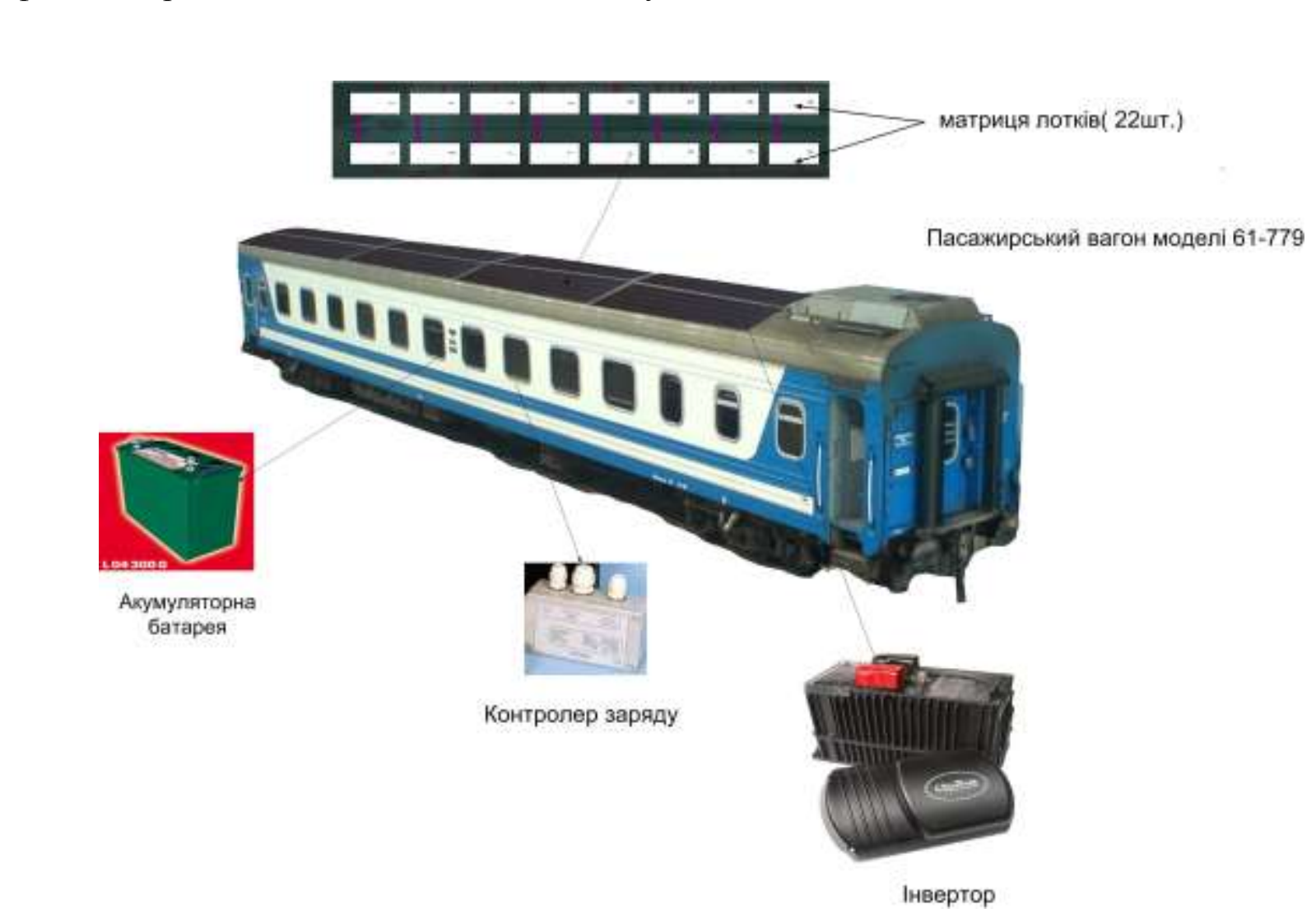

Рис. 2. Фотоелектрична система пасажирського вагона

Необхідно зазначити, що економіка України має відповідні потужності 3 виробництва необхідних компонентів та створення інфраструктури сонячної енергетики. Виробничі можливості тільки таких гігантів мікроелектроніки, як виробничі об'єднання «КВАЗАР», «ІРВА» (м. Київ), «Гравітон» (м. Чернівці), «Хартрон» (м. Харків), «Гамма» i «Електроавтоматика» (м. Запоріжжя), «Дніпро» (м. Херсон), «Позитрон» (м. Івано-Франківськ) дозволяють проводити повний технологічний цикл створення сонячних елементів. Україна має висококваліфікований науковий потенціал в цій галузі (Інститут фізики напівпровідників та Інститут електродинаміки НАНУ, Київський національний університет ім. Тараса Шевченка, Чернівецький національний університет ім. Ю.Федьковича, Національний технічний університет “КПІ").

Висновки 3 дослідження i перспективи, подальший розвиток $\mathbf{y}$ даному напрямку. Проведений аналіз робіт вітчизняних та закордонних авторів 3 метою дослідження світового досвіду впровадження енергозберігаючих технологій свідчить про широкі перспективи використання сонячної енергетики у сфері вагонного господарства та актуальність вирішення проблеми обладнання вітчизняного рухомого складу (вагонів) південного прямування сонячними модулями як додатковим джерелом електричної енергії. 


\section{Список використаних джерел}

1. Оборудование нетрадиционной и малой энергетики [Текст] / под ред. С.П. Осипова. - AО ВИЕН, 2000.

2. Солнечные батареи [Текст] / под ред. Д.Ю. Потапова. - Днепропетровск: Вища школа, 1982.

3. Альтернативная энергетика [Текст] / под ред. В.С. Кирилова. - М.: Госэнергоиздат, 1983.

4. http://www.greencarcongress.com/2005/10/italian_trains_.html

5. http://www.rpd.univ.kiev.ua/new/ukr/cikavo/solarenergy.php

6. http://www.discoversolarenergy.com/solar/radiation.htm

7. Спосіб альтернативного енергозабезпечення вагонів рейкового рухомого складу від фотоелектричної системи [Текст]: пат. 101017 Україна: а 201033363 / Бондаренко В.В.; заявник та власник Українська державна академія залізничного транспорту, заявл. 17.09.2010; опубл. 25.02.2013, Бюл. № 4. - 5c.

Рецензент д-р техн. наук, професор I.Е. Мартинов

Бондаренко Вячеслав Володимирович, кандидат технічних наук, доцент кафедри вагонів Української державної академії залізничного транспорту. Тел.: (057) 730-10-35. E-mail: bonvya@mail.ru.

Скуріхін Дмитро Ігоревич, асистент кафедри вагонів Української державної академії залізничного транспорту. Тел.: (057) 730-10-35.

Гончаренко Максим Вікторович, магістрант кафедри вагонів Української державної академії залізничного транспорту. Тел.: (057) 730-10-35.

Bondarenko Vyacheslav, cand. of techn. sciences, assistant professor of the department vagons Ukraine State Academy of Railway Transport. Tel.: (057) 730-10-35. E-mail: bonvya@mail.ru

Skurihin Dmitry, assistant of the department vagons Ukraine State Academy of Railway Transport. Tel.: (057) 730-10-35. Goncharenko Maxim Viktorovich, master student the department vagons Ukraine State Academy of Railway Transport. Tel.: (057) 730-10-35. 